\title{
Persistent androgen receptor addiction in castration-resistant prostate cancer
}

\author{
Michael T. Schweizer ${ }^{*}$ and Evan Y. Yu ${ }^{*}$
}

\begin{abstract}
It is now understood that persistent activation of the androgen receptor (AR) signaling pathway often underlies the development of castration-resistant prostate cancer (CRPC). This realization led to renewed interest in targeting the AR and ultimately to the development of the potent next-generation AR-directed agents abiraterone and enzalutamide. While these drugs prolong survival in men with CRPC, they are unfortunately not curative. Perhaps not surprisingly, evidence points to persistent AR signaling as one of the key drivers by which resistances to these agents develops. In this context, activation of the AR signaling program can occur through a number of molecular adaptations, including alterations leading to persistent canonical AR signaling (e.g., AR amplification/overexpression, elucidations/concentration of intratumoral androgens), activation of the AR program via feedback pathways (e.g., AKT/mTOR/Pi3K, HER2/Neu), and activation of the AR program via mutation or substitution (e.g., AR ligand binding domain mutation; AR splice variants; glucocorticoid receptor signaling). This review will provide an overview of the more clinical relevant (i.e., druggable) pathways that have been implicated in the emergence of drug resistance in men with CRPC and highlight some of the ongoing efforts towards developing therapeutics to impair these mechanisms.
\end{abstract}

Keywords: Prostate cancer, Castration-resistant prostate cancer, Androgen receptor, Androgen receptor splice variant, Drug resistance, Signaling pathway

\section{Background}

Androgen deprivation therapy (ADT) has remained the backbone of treatment for advanced prostate cancer since the remarkable palliative effects of surgical castration were first described by Huggins and Hodges back in the 1940s [1]. While ADT is effective at controlling metastatic prostate cancer, for the vast majority of patients, these benefits are short lived, and most will progress to the lethal phenotype of the disease, so called castrationresistant prostate cancer (CRPC).

CRPC is defined as progressive prostate cancer in the face of castrate serum testosterone levels $(\leq 50 \mathrm{ng} / \mathrm{dL}$ ) $[2,3]$. Older literature has described this disease state as "hormone refractory"; however, the term "castrationresistant" has been adopted largely due to the increasing recognition that androgen receptor (AR) signaling still plays a vital role in driving prostate cancer growth and remains a viable target in this disease space [4]. Indeed, the development of newer drugs that function to

\footnotetext{
* Correspondence: schweize@uw.edu; evanyu@u.washington.edu Division of Oncology, Department of Medicine, University of Washington/ Fred Hutchinson Cancer Research Center, Seattle, WA 98109, USA
}

inhibit ligand-AR interaction (e.g., abiraterone (an inhibitor of extragonadal androgen synthesis) and enzalutamide (a potent irreversible AR antagonist)) have provided proof of principle that the AR remains an important driver of CRPC growth [5-8].

Perhaps not surprising, more complete AR signaling inhibition with drugs like abiraterone and enzalutamide has not proven curative, with resistance typically emerging within a year of drug initiation [5-8]. Our understanding of resistance mechanisms operating to drive continued CRPC growth after receipt of either abiraterone or enzalutamide has clarified that persistent AR signaling is still one of the major drivers.

Persistent activation of the AR signaling program occurs both not only through molecular adaptations of the $A R$ itself but also through a number of accessory oncogenic pathways promoting persistent AR activation, ultimately leading to progressive prostate cancer. Broadly, these mechanisms include alterations leading to persistent canonical AR signaling (e.g., AR amplification/overexpression, elucidations/concentration of intratumoral androgens), activation of the AR program via feedback 
pathways (e.g., AKT/mTOR/Pi3K, HER2/Neu), and activation of the AR program via mutation or substitution (e.g., AR ligand binding domain mutation, AR splice variants, glucocorticoid receptor signaling) [9-25].

Detailed reviews have been written on any one of these pathways, and our goal is not to catalog the numerous molecular adaptations that can precede the emergence of CRPC drug resistance. Rather, we seek to provide an overview of the more clinical relevant (i.e., druggable) pathways that have been implicated in the emergence of drug resistance and to highlight some of the ongoing efforts towards developing therapeutics to impair these mechanisms. This review will therefore focus on the evidence for several key mechanisms implicated in promoting sustained AR signaling, with an emphasis on those that may be targetable in the near term.

\section{Review}

\section{Androgen receptor function and structure}

The AR is a nuclear transcription factor encoded on the $\mathrm{X}$ chromosome at position Xq11-Xq12 [26, 27]. It contains eight exons and is composed of four domains: the N-terminal domain (i.e., transcriptional activation domain) (exon 1), DNA-binding domain (exons 2 and 3), a hinge region (exons 3 and 4), and the ligandbinding domain (i.e., C-terminal) (exons 4-8) (Fig. 1). An overly simplistic model of canonical AR signaling involves: (1) androgen binding the AR ligand binding domain, (2) dissociation of chaperone proteins (i.e., heat shock proteins), (3) AR nuclear transport and dimerization (likely through microtubule interaction with the hinge region), (4) binding of dimerized AR to androgen response elements (ARE) located within the promoters of AR target genes, (5) recruitment of AR co-activators, and (6) transcription of AR target genes. A number of additional events, such as AR phosphorylation and interaction with other co-regulators and transcription factors likely also play a role in modulating transcription of AR target genes [28].

The $A R$ represents perhaps the first described lineage-specific oncogene, with prostate cancer demonstrating a persistent addiction to AR- ignaling even in its late stages-a reflection of its emergence from normal prostatic epithelium [29, 30]. The survival of a given prostate cancer cell is tightly linked to persistent AR signaling, and as such, these malignant cells will undergo a number of adaptive changes to ensure persistent AR signaling. Reflective of the reliance of prostate cancer on the expression of AR target genes is the observation that over $70 \%$ of CRPC cases harbor $A R$ pathway aberrations, with AR transcriptional activity persisting in the majority of cases of CRPC [31].

\section{Persistent canonical AR pathway activation}

The observation that AR-regulated genes (e.g., PSA) remain expressed in a castration-resistant state renewed interest in targeting the AR in men that had progressed on LHRH analogue therapy. Ultimately, this work led to the development of drugs that more effectively inhibit the ligand-AR interaction. Abiraterone, a CYP-17 inhibitor capable of inhibiting extragonadal testosterone synthesis (i.e., adrenal and intratumoral) was approved on the basis that it significantly prolongs survival in both the pre- and postdocetaxel spaces [6, 7, 32]. Approval for enzalutamide, a potent AR antagonist, was granted on the basis of a survival advantage in similar patient populations [5, 8]. The clinical efficacy of abiraterone and enzalutamide has provided proof of principal that canonical AR signaling is an important driver of CRPC growth that can be targeted for clinical gains.

Interestingly, a correlation between increased fulllength AR (AR-FL) expression and $A R$ copy number gains with the emergence of resistance to second generation AR-directed agents has been documented $[9,11,33,34]$. This implies that persistent canonical AR signaling is likely engaged even in the presence of drugs that should otherwise be able to inhibit ARFL from interacting with its ligand (i.e., androgens). This could be a result of pharmacokinetic issues whereby drugs are unable to reach sufficient concentrations within the tumor microenvironment or that intratumoral steroidogenesis is able to overcome the inhibitory effects of these agents $[35,36]$. A more definitive explanation for this effect is needed and continues to be an area of active research.

\section{$A R$ overexpression and copy number alterations}

One of the more commonly observed events as prostate cancer progresses from a hormone-sensitive to castration-resistant state is the adaptive upregulation of the AR, a finding supported by preclinical as well as clinical studies $[13,20]$. Chen and colleagues demonstrated that a number of prostate cancer cell lines will adaptively increase their AR expression as they are passaged in castrate mice over time, and that this overexpression of AR is sufficient to induce resistance to the effects of surgical castration as well as treatment with the first-generation anti-androgen bicalutamide [13]. AR overexpression as a driver of resistance is also supported by data from rapid autopsy programs showing that AR expression is increased in patients that have died from CRPC [37, 38]. These findings provided a strong rationale for developing drugs like abiraterone and enzalutamide to target persistent AR signaling in men with CRPC. 


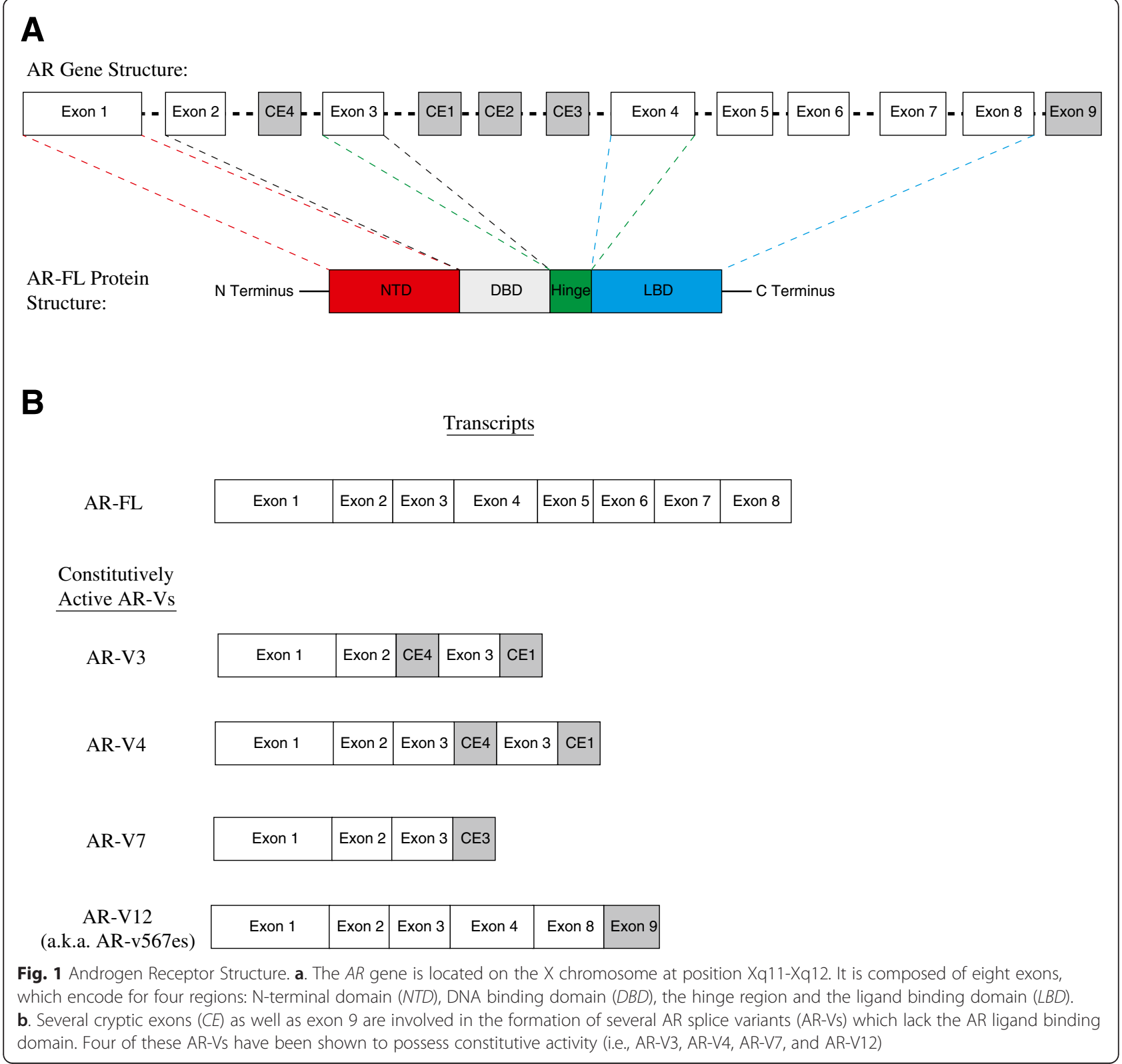

In addition, an adaptive increase in AR expression and $A R$ copy number gain has also been observed in circulating tumor cells (CTCs) as well as cell-free circulating tumor DNA (ctDNA) from patients with CRPC receiving next-generation AR-directed therapies (i.e., abiraterone and enzalutamide)-implicating this as mechanism by which cell growth can escape the inhibitory effects of these drugs $[9,11,33,34]$. Perhaps more indicative of the importance AR overexpression plays in promoting CRPC growth comes from the results of a recently published, large metastatic biopsy program enrolling men with CRPC [31]. In that paper, 150 men with metastatic CRPC underwent biopsy and had sufficient tumor material to undergo integrative genomics analysis (i.e., whole exome and transcriptome sequencing). That study revealed that the most frequently observed genetic alteration was $A R$ copy number gain, occurring in $45 \%$ of cases.

\section{Maintenance of intratumoral androgens}

In addition to overexpressing AR, there is evidence that the maintenance of androgens within the tumor microenvironment may also be an important means by which canonical AR signaling drives castrate-resistant growth. In men with hormone-sensitive, localized prostate cancer, it has been found that intraprostatic androgens will fall by $\sim 75 \%$ following initiation of an LHRH analogue therapy, with residual androgen levels sufficient to drive 
expression of AR-activated genes such as PSA [39, 40]. In addition, Montgomery and colleagues have shown that compared to benign prostatic tissue and primary tumors from eugonadal patients, metastases in men with CRPC had significantly elevated testosterone levels [19]. Interestingly, increased mRNA expression of several steroidogenic enzymes (i.e., 3ßHSD, CYP17A1, AKR1C3, and SRD5A2) accompanied the increased testosterone concentrations found within metastatic CRPC foci-providing a mechanistic explanation for why increased androgens levels are found within the metastatic tumor microenvironment (Fig. 2).

In support of the putative role steroidogenic enzymes play in sustaining intratumoral androgens and subsequent AR activation, cell culture and xenografts models of CRPC have demonstrated that AKR1C3mediated steroidogenesis can lead to the emergence of resistance to next-generation AR-directed therapies $[41,42]$. Further evidence for the importance that intratumoral androgen biosynthesis plays in promoting CRPC resistance is provided through experiments exploring the effects of impairing the activity of key steroidogenic enzymes. For instance, inhibiting AKR1C3, an enzyme involved in converting DHEA-S into the potent AR ligands testosterone and dihydrotestosterone (DHT), has been shown to inhibit prostate cancer cell growth in cell culture and xenograft models [43, 44]. In addition, a synergistic anti-tumor effect when indomethacin (an AKR1C3 inhibitor) is combined with either abiraterone or enzalutamide has been reported in otherwise resistant prostate cancer cell lines [41, 42]. Clinical trials to test the effects of inhibiting AKR1C3 are currently being developed.

The steroidogenic enzyme $3 \beta \mathrm{HSD}$ (encoded by either $H S D 3 B 1$ or $H S D 3 B 2$ ) is able to catalyze the conversion of androstenediol to testosterone and also catalyzes the initial rate-limiting step in converting DHEA to DHT [45]. As noted above, 3ßHSD mRNA levels are higher in metastases from men with CRPC and correlate with increased intratumoral androgen levels [19]. A gain-offunction mutation in $3 \beta \mathrm{HSD}$ has also been described that results in increased DHT production and may be selected for following chronic castration (i.e., in a castration-resistant state) [12]. This mutation may also represent a mechanism by which abiraterone resistance occurs, as increased 3ßHSD activity can result in persistent adrenal steroidogenesis in spite of CYP17 inhibition. These observations have implicated 3ßHSD as a means by which ligand is able to persist in spite of ADT, raising the specter that $3 \beta \mathrm{HSD}$ activity may be one of the mechanisms leading to castration resistance and indicating that $3 \beta \mathrm{HSD}$ may be a viable drug target [16].

Of note, abiraterone does function as a weak $3 \beta \mathrm{HSD}$ inhibitor, and it has been proposed that increased abiraterone exposure may result in more complete 3 $3 \mathrm{HSD}$ inhibition [8]. Dose-escalated abiraterone may therefore have the resultant effect of decreasing the metabolic flux to DHT and potentially reverse resistance to

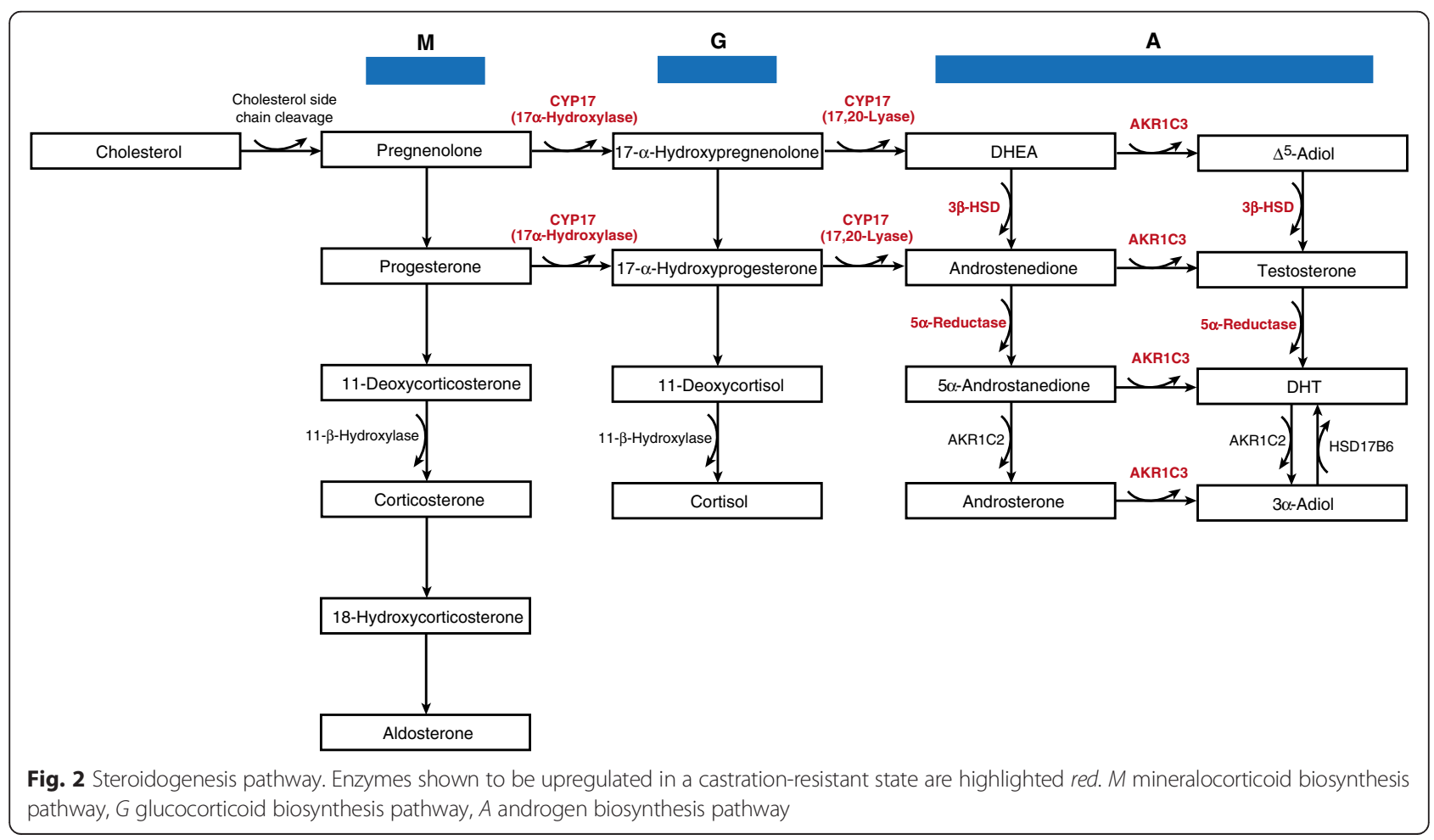


standard dose abiraterone. A clinical trial testing if dose-escalated abiraterone can further suppress intratumoral androgen levels (presumably through impairing $3 \beta \mathrm{HSD}$ activity) is currently underway (clinicaltrials.gov: NCT01503229). Interestingly, $3 \beta \mathrm{HSD}$ has also been shown to catalyze the conversion of abiraterone to $\Delta^{4}$-abiraterone (D4A), a more potent compound able to inhibit several steroidogenic enzymes and antagonize the AR to a degree comparable to enzalutamide [17]. Whether a resistant phenotype emerges following treatment with abiraterone may be in part due to the degree to which $3 \beta \mathrm{HSD}$ is able to promote DHT vs. D4A production. More work to understand the relative contribution that DHT and D4A synthesis plays in promoting abiraterone response/resistance is needed.

Enhanced androgen and hormone substrate uptake into the tumor microenvironment may be another explanation accounting for the higher concentration of androgens found within metastatic foci. Androgen uptake is mediated by the OATP (organic anion transporting polypeptide) transporter and polymorphisms in the SLCO family of genes encoding the OATP transporters have been found to associate with outcomes [22, 23, 46-49]. For instance, SNP alleles associated with enhanced androgen transport or increased SLCO expression have been correlated with increased prostate cancer-specific mortality and higher rates of disease progression [22, 23, 46, 48]. Preclinical studies have shown that statins are able to competitively bind SLCO2B1 and prevent uptake of the testosterone precursor DHEAS $[23,50]$. Retrospective data has also shown a correlation between statin use and prolonged time to progression [50]. Whether this correlation is due to preventing androgen uptake by the OATP transporter SLCO2B1 or due to decreasing cholesterol-an essential substrate for all steroid hormones-remains to be seen [51].

AR mutations, variants, and alternate hormone activation In addition to activating the AR transcriptional program via canonical full-length AR signaling, variants of the AR that occur through alternative splicing or mutations in the ligand binding (i.e., $\mathrm{C}$ terminal) domain of the AR are also able to keep AR signaling engaged in a castration-resistant state $[9,11,20,52-56]$. In addition, other nuclear hormone receptors, such as the glucocorticoid receptor (GR), are able to activate a seemingly similar transcriptional program to the AR and may be a mechanism by which prostate cancer cells develop resistance to drugs that block AR signaling by disrupting the AR ligand interaction [57-60].

\section{AR point mutations}

A number of point mutations within the ligandbinding domain of the AR have been described that result in resistance to first-generation anti-androgens (e.g., flutamide, nilutamide, and bicalutamide) [61, 62]. Some of these mutations result in increased AR activity upon exposure to these agents, likely explaining why some men experience an anti-androgen withdraw effect following their cessation [63]. Similarly, the AR mutation F877L has been found to associate with resistance to the secondgeneration AR antagonists enzalutamide and ARN-509, resulting in AR activation upon exposure to these agents [34, 64-66]. More recently, preclinical models have demonstrated that the AR antagonist ODM-201 is able to inhibit F877L prostate cancer mutant cell growth [67]. Recent phase $1 / 2$ testing has demonstrated that ODM201 is well tolerated and is active in men with CRPC [68]. This study did not, however, assess for the presence of the F877L mutation, and ODM-201's activity in this subset of patients remains undefined.

\section{AR splice variant}

Over the last few years, it has become increasingly well recognized that in addition to point mutations, alternative splicing events that lead to constitutively active AR variants (AR-Vs) are another clinically relevant means by which prostate cancer is able to progress in spite of agents that effectively disrupt the AR-ligand interaction (Fig. 1) [9, 20, 25, 31, 53-55, 69]. The AR-Vs, the most commonly occurring AR-V being AR-V7, retain the ability to activate their transcriptional program in spite of lacking the AR ligand-binding domain [70]. A recent prospective biomarker trial reported by Antonarakis et al. found an association between the emergence of AR-V7 mRNA transcripts, as measured from CTC, and resistance to abiraterone and enzalutamide [9]. This data provides an elegant biologic rationale for why drugs that interfere with the AR-ligand interaction may not be effective in patients harboring certain AR-Vs at significant levels; however, it should be noted that increased AR-FL expression always accompanied the emergence of AR-V7 transcripts and was also found to associate with drug resistance (albeit not as strongly as the presence of AR-V7) [20, 52-56]. Interestingly, AR-V7 does not appear to be predictive for lack of response to docetaxel-providing a rationale for precision oncology trials stratifying patients between AR-directed therapies and chemotherapies on the basis of AR-V status [71].

Recently, Steinestel et al. reported their experience using a method similar to the one employed by Antonarakis and colleagues for detecting AR-V7 transcripts [72]. They also found that the presence of AR-V7 transcripts associated with a lack of PSA response to abiraterone or enzalutamide; however, it should be noted that one out of five AR-V7-positive patients in this trial had a PSA response (i.e., $\geq 50 \%$ decline in PSA from baseline) to abiraterone, which is in conflict 
with the results reported by Antonarakis et al. Needless to say, further studies to validate the utility of detectable ARV7 transcripts as a predictive and/or prognostic biomarker, ideally in the context of a randomized therapeutic trial, are needed. In addition, mechanistic studies are need in order to determine if AR-Vs are drivers of resistance or merely indicative of a larger resistance program being at play.

The N-terminal domain of the AR is critical for AR transactivation and subsequent activations of its transcriptional program [73]. As noted above, deletion of the C-terminal (i.e., ligand-binding domain) may result in constitutive AR activity, and as such, there are a number of ongoing efforts to develop drugs capable of inhibiting the N-terminal domain or its co-activators/ epigenetic regulators, as a means to overcome AR-Vmediated drug resistance $[10,18,74]$. In addition to directly targeting the $\mathrm{N}$-terminal domain, drugs intended to suppress AR-V expression are also being developed [75-78].

Due to the fact that the AR N-terminal is inherently unstructured, developing drugs that block AR-signaling through impairing $\mathrm{N}$-terminal domain activity is not trivial [79]. Epi-001 and its analogues (e.g., Epi-506) are small molecule antagonists designed to target the AR $\mathrm{N}$-terminal domain. They reportedly covalently bind to the $\mathrm{N}$-terminal domain, thus inhibiting the proteinprotein interactions required for AR-mediated transcription [80]. Importantly, these $\mathrm{N}$-terminal domain antagonists have been shown to retain activity in prostate cancer cell lines expressing AR-Vs. Of note, Epi-001 may have a broader mechanism of action than first described [81]. It has been shown to have general thiol alkylating activity, resulting in multi-level effects on prostate cancer cells. In addition to covalently binding to the AR $\mathrm{N}$-terminal domain, Epi-001 has been shown to inhibit transcription of the $A R$ gene and to modulate PPAR $\gamma$ activity. Likely as a result of these diverse mechanisms of action, Epi-001 has also been shown to inhibit the growth of AR-null prostate cancer cell lines. A phase I/II trial testing Epi-506, a pro-drug of Epi-001, is planned to open in the near future [74].

The AR transcriptional machinery is immensely complex and involves not only AR binding to the enhancer elements of target genes but also the assembly of RNA polymerase II with a number of co-activator proteins [31, 82-84]. Much work has gone into understanding the key regulators of AR-mediated transcription, in an effort to identify novel therapeutic targets. Genetic knockdown of HDAC1 or HDAC3 or treatment with an HDAC inhibitor has been shown to prevent the assembly of the AR-transcriptional complex and prevent expression of AR-mediated genes [84]. Unfortunately, a small phase II study testing the HDAC inhibitor romidepsin failed to demonstrate sufficient activity in patients with CRPC [85]. Another strategy by which AR signaling could be disrupted involves inhibiting one or more AR co-activators. Bromodomain 4 (BRD4) and mixed-lineage leukemia (MLL) likely function to regulate AR activity and have both been shown to physically interact with the AR N-terminal domain [10, 18]. Importantly, inhibiting BRD4 or MLL results in an antitumor effect in AR signaling-competent models of CRPC. It should be noted, however, that epigenetic regulators of AR transcription are unlikely to be specific to the AR, and their inhibition may result in altering the transcriptional program across an array of bystander genes. Prostate cancer-specific studies testing MLL and bromodomain inhibitors have not begun yet, but seem likely to occur in the future based on this preclinical data.

Multiple drugs have also been shown to suppress AR-V transcripts and/or protein express. The novel AR-directed therapeutic galeterone has reportedly three different mechanisms by which can prevent AR signaling: (i) inhibiting extragonadal androgen synthesis through CYP17 inhibition (an enzyme critical to adrenal and possibly intratumoral androgen production), (ii) preventing AR nuclear translocation, and (iii) by promoting AR-FL, mutant AR, and AR-V proteosomal degradation [75, 76, 86]. Based on encouraging results from the phase I/II trial, a phase III study testing galeterone vs. enzalutamide in men with AR-V7+ CRPC is planned [87].

Similar to galeterone, the anti-helminthic drug niclosamide has been shown to potentially suppress AR-V expression [77]. Interestingly, it has no effect AR-V7 mRNA transcript levels. Instead, it has been reported to enhance AR-V7 degradation, resulting in an antineoplastic effect in otherwise enzalutamide-resistant prostate cancer cell lines. While this effect is modest when niclosamide is used alone, it has a synergistic effect when combined with enzalutamide, likely because niclosamide does not have effect on AR-FL. Niclosamide's pharmacokinetics may be a barrier to developing it as a prostate cancer drug, however, as it has been found to have poor bioavailability (albeit only in one small study) [88]. As a strategy to overcome this issue of bioavailability, a phase I trial testing enzalutamide plus high-dose niclosamide in AR-V7+ men with CRPC is being pursued (clinicaltrials.gov: NCT02532114). Of note, because of niclosamide's specificity for AR-V7, this trial may shed some light on the question of whether AR-V7 is a driver of or merely a marker for resistance. That is, if clinical activity is observed with combination treatment and AR-V7 expression is suppressed, that would speak to AR-V7 functioning as a driver of resistance. On the other hand, if there is clinical activity and AR-V7 expression is unaffected, it would seem more plausible that $\mathrm{AR}-\mathrm{V} 7$ is a biomarker for a larger resistance program. If AR-V7 expression is suppressed and no clinical activity 
is observed, this may offer some evidence to refute ARV7 function as a driver of resistance. Clearly, a small phase I study will not put this issue to rest, but it could provide valuable insights regarding the biology of AR-V7 nonetheless.

Preclinical models have shown that castrate androgen levels are able to rapidly induce the expression of AR-V7 and conversely that supplementation with supraphysiologic androgen concentrations can acutely suppress their expression [25, 78]. Based on additional evidence that supraphysiologic androgens are able to exert a paradoxical anti-tumor effect in models of CRPC, a pilot study testing pharmacologic doses of testosterone was launched [78]. This study documented radiographic and PSA responses in $\sim 50 \%$ of enrolled men. Interestingly, the authors observed a possible resensitization effect whereby following treatment with testosterone, re-challenge with an AR antagonist (i.e., enzalutamide or bicalutamide) resulted in a PSA response. Similarly, men that had previously progressed on the next-generation AR-directed therapies abiraterone and enzalutamide demonstrated high response rates upon treatment with the alternate agents-contrary to reports of clinical cross-resistance when these agents are used sequentially $[6,89-96]$. This effect needs to be confirmed in larger prospective studies, but it remains possible that suppression of AR-FL and/or AR-Vs may explain why some patients appear to be more sensitive to drugs that inhibit AR signaling following testosterone therapy. A clinical trial specifically testing the ability of pharmacologic dose testosterone to act as re-sensitizing agent is currently underway (clinicaltrials.gov: NCT02090114).

Alternate nuclear hormone receptor mediated AR activation The GR is another nuclear hormone transcription factor and has been shown to potentially drive castrationresistant cell growth through activating a similar transcriptional program to the AR [57-59]. A recently reported neoadjuvant trial testing abiraterone plus LHRH analogue vs. abiraterone, enzalutamide, and LHRH analogue for 6 months pre-prostatectomy in men with high-risk localized prostate cancer supports a role for both AR-V and GR signaling in conferring resistance to these potent combinatorial therapies [60]. The authors found that the loss of AR ligand binding domain, as measured by immunohistochemistry for the AR-C terminus,and increased GR expression were significantly correlated with the higher tumor epithelial volume.

Somewhat disappointingly, a small study testing the GR antagonist mifepristone did not demonstrate evidence of clinical efficacy in CRPC patients; however, the authors noted an increase in testosterone and DHT levels after 29 days of therapy-presumably due to feedback mechanism leading to increased ACTH production and in turn higher adrenal androgen biosynthesis [97]. Another strategy being explored is whether combining mifepristone with enzalutamide, to block any residual androgens from binding AR, is safe and will lead to improved outcomes (clinicaltrials.gov: NCT02012296). Whether this strategy will be effective remains to be seen; however, it should be noted that completely inhibiting GR signaling is not compatible with life, and therapeutic strategies aimed at completely inhibiting its function are not likely viable [57].

\section{Alternative pathway AR activation}

A number of additional oncogenic signaling pathways interact with and promote persistent AR transcriptional activity [98]. Pathways commonly affected include the PI3K, WNT, JAK/STAT, and growth factor pathways. In addition, phosphoproteomic analyses have implicated a number of tyrosine kinase signaling pathways as potential prostate cancer drivers (e.g., SRC, EGFR, RET, ALK, and MAPK1/3) [15]. Many of these pathways demonstrate significant cross talk not only with the AR but also between each other-making it exceedingly difficult to develop an effective therapeutic strategy that focuses on impairing only one of the nodes within these complex signaling networks. Below is a discussion of some of the more commonly altered pathways in prostate cancer (Fig. 3).

\section{PI3K pathway}

Somatic alterations in the PI3K/Akt/mTOR signaling pathway occur in nearly $50 \%$ of CRPC cases, and there is evidence that significant cross talk exists between this and the AR signaling pathway as well as other oncogenic pathways (e.g., RAS/RAF/MEK) [31, 99-102]. As evidence of the close relationship between the PI3K and AR signaling pathways, PTEN-deficient models of prostate cancer have revealed a reciprocal feedback relationship between these two pathways whereby suppression of AR signaling promotes PI3K pathway activation, and conversely, suppression of PI3K signaling results in AR activation [102]. Importantly, this model demonstrated that dual inhibition of both pathways resulted in a profound anti-tumor effect.

Genetic aberrations commonly occurring along the PI3K pathway include biallelic loss of PTEN; mutations, amplification, and activating fusions in PIK3CA; activating mutations in $P I K 3 C B$; and activating mutations in AKT1 [31]. PTEN is the most commonly affected gene in this pathway and is altered in approximately $40 \%$ of CRPC cases [103, 104]. It acts as a negative regulator of $\mathrm{PI} 3 \mathrm{~K} / \mathrm{Akt} / \mathrm{mTOR}$ signaling and when inactive or lost leads to pathway over activation. The PI3K signaling pathway has diverse array of functions and has been implicated in promoting prostate cancer growth, survival, proliferation, migration, stem cell-like properties and 


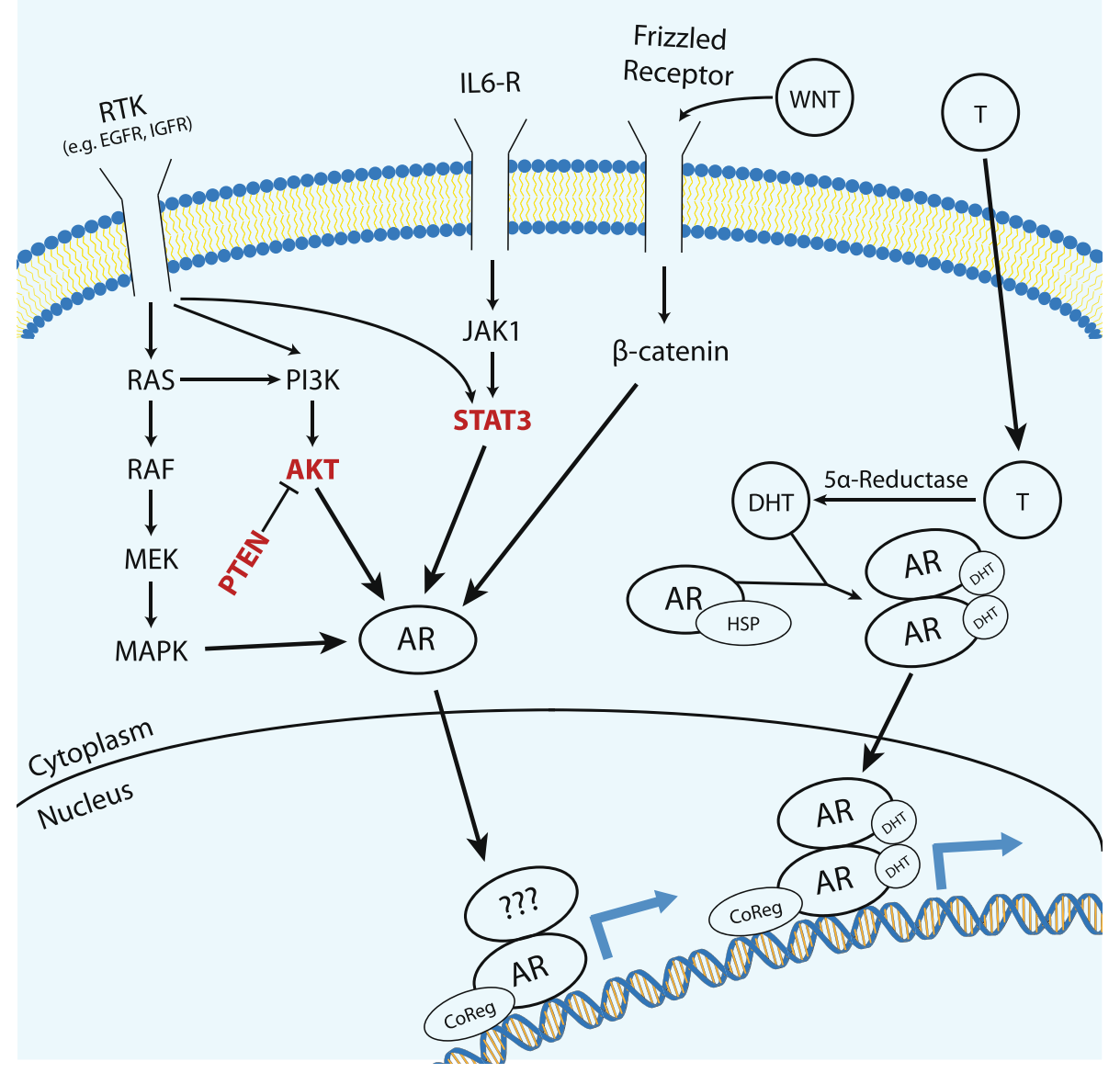

Fig. 3 Androgen receptor activation pathways. AR transcription can occur either through canonical AR-FL signaling or through cross-talk between alternative signaling pathways. Ligand-independent AR transcription likely occurs through a number of mechanisms and may involve the formation of AR homodimers (as is the case with the AR-FL canonical signaling pathway) or heterodimerization between AR-FL, AR-Vs, and AR-mutants. Cross-talk between signaling pathways likely augment AR transcriptional activity in several ways, including through $\mathrm{N}$-terminal phosphorylation, or by promoting AR nuclear translocation. Key nodes affected by several pathways are highlighted in red. RTK receptor tyrosine kinases, T testosterone, HSP heat-shock proteins, IL6-R IL-6 receptor, CoReg co-regulators

angiogenesis [98, 105-108]. Speaking to this pathways importance, PTEN loss has been correlated with more advanced stage and higher Gleason scores [109, 110].

There have been a number of efforts to target the PI3K/Akt/mTOR pathway, and Pan-PI3K, Akt and mTOR inhibitors are all currently in clinical testing [101, 111-117]. To date, most of the prostate cancerspecific experience targeting this pathway comes from studies testing allosteric mTOR inhibitors, with these studies all generally failing to demonstrate sufficient activity to warrant further study [111-115]. There are a number of explanations that may explain this lack of activity. For one, allosteric mTOR inhibitors only inhibit mTORC1 activity, and evidence supports mTORC2 as being an important activator of Akt in prostate cancer cells [118]. Increased reciprocal signaling through other oncogenic pathways (e.g., AR and RAS/RAF/MEK) could also render these agents ineffective. Finally, allosteric mTORC1 inhibitors do not inhibit key downstream effectors such as eIF4E, a rate-limiting initiation factor that has been implicated in mTOR-mediated translation of a number of oncogenic genes [106]. Ongoing efforts to target this pathway more effectively include developing ATP dual mTORC1/mTORC2 inhibitors, Akt inhibitors, and pan-PI3K inhibitors [101, 105, 119].

\section{Epidermal growth factor pathways}

Signaling through the epidermal growth factor (EGF) and its family of receptors (i.e., EGFR, HER2/Neu, erbB3, and erbB4) has also been implicated in the 
growth and progression of prostate cancer [120]. For instance, HER2 has been shown to be inducible in castrate conditions and to result in elevated AR target genes such as PSA [121-123]. These pathways' effects are likely in large part mediated through MAPK activation, which can lead to phosphorylation of the AR N-terminal and subsequent ligand-independent transcription of AR target genes [24].

Based on the aforementioned observations, a handful of trials exploring the utility of targeting HER2 and/or EGFR signaling have been completed [124]. A phase II trial testing afatinib, a tyrosine kinase inhibitor (TKI) targeting EGFR and HER2, alone and in combination with nintedanib, a multi-targeted anti-angiogenic TKI, in men with CRPC was recently reported [125]. In that study, afatinib did not demonstrate any clear anti-tumor activity, with all 20 patients on the afatinib monotherapy arm progressing after 12 weeks of therapy. Lapatinib, another dual EGFR/HER-2 TKI, has also been tested in prostate cancer population [126-128]. In a single-arm phase II study targeting men with biochemically recurrent disease (i.e., non-metastatic patients with an elevated PSA), the primary endpoint of $\mathrm{PSA}_{50}$ response (i.e., $\geq 50 \%$ decline in PSA from baseline) was not observed in any patients; however, it did appear to favorably augment PSA kinetics, resulting in a decreased PSA slope [126]. Another study in ADT-naïve patients (metastatic [5] and non-metastatic $[N=18]$ ) also documented no $\mathrm{PSA}_{50}$ responses (the primary endpoint). Finally, in a phase II trial enrolling men with CRPC (both metastatic $[N=14]$ and non-metastatic $[N=7])$, lapatinib was also shown to have minimal single agent activity, with only $1 / 21$ patients achieving a $\mathrm{PSA}_{50}$ response (the primary endpoint) [127]. Similarly disappointing results were observed in studies testing the monoclonal anti-HER2 antibodies trastuzumab and pertuzumab in patients with CRPC $[129,130]$. In total, these trials enrolled 86 patients, with none of them demonstrated a $\mathrm{PSA}_{50}$ response.

\section{Insulin-like growth factor pathway}

Similar to EGFs, the insulin-like growth factors (IGFs) have far-reaching biologic effects, promoting the growth, development, and survival of cells [131]. IGF signaling as it pertains to prostate cancer growth and progression is likely mediated through type I IGF receptor (IGF-IR) [132]. IGF-IR signaling demonstrates significant cross talk with the AR, modulating the AR transcriptional profile, AR nuclear translocation, and AR phosphorylation profile [132-134]. IGF-I levels have also been linked to a greater risk of prostate cancer progression [135-138].

Based on these observations, a randomized phase II study in men with hormone-sensitive metastatic prostate cancer comparing androgen deprivation therapy with or without cixutumumab, a monoclonal antibody targeting
IGF-IR, was launched [139]. Ultimately, there was no significant difference in the rate of undetectable PSA at 28 weeks (the primary endpoint) with the addition of cixutumumab. Cixutumumab has also been studied in combination with mitoxantrone in men with CRPC and was also found to have insufficient activity to warrant further development [140]. Studies evaluating cixutumumab as part of a targeted combination strategy have yet to be reported (clinicaltrials.gov: NCT01 026623, NCT00683475).

\section{JAK/STAT pathway}

Cytokines, particularly IL-6, have also been implicated in the maintenance of AR signaling-likely through enhanced JAK/STAT signaling. IL-6 has also been shown to associate with advanced stage prostate cancer and survival [141-144]. STAT3, one of the downstream effectors of IL-6, can lead to AR-STAT3 complex formation and subsequent AR activation [145]. Of note, EGFR signaling is also able to promote AR-STAT3 complex formation, and STAT3 has been shown to increase EGFR-mediated AR transcriptional activation-likely indicating that a complex signaling network exists between AR signaling and STAT3, IL-6, and EGFR [146].

Agents targeting this pathway include siltuximab, a monoclonal antibody targeting IL-6. In a phase I presurgical neoadjuvant study testing siltuximab as a monotherapy, it was shown to be well tolerated, associates with increased Ki-67 expression (a marker of apoptosis), and results in downregulation of genes downstream of IL-6 [147]. This agent was also tested in a phase I study combining it with docetaxel at the standard dose of $75 \mathrm{mg} / \mathrm{m}^{2}$ IV every 21 days [148-150]. The combination was well tolerated, and no PK interaction was noted. Not surprisingly, since it was given in combination with docetaxel, a PSA response rate of $62 \%$ was observed. In contrast, a phase II study comparing siltuximab plus mitoxantrone vs. mitoxantrone alone was prematurely terminated due to concern for lack of efficacy at interim analysis [151].

\section{WNT pathway}

Wnt signaling plays an important role in early embryonic development as well as in promoting the growth and progression of several malignancies [131, 152]. Canonical Wnt signaling leads to the accumulation of $\beta$-catenin within the nucleus and leads to target gene transcription. Cross talk between the canonical Wnt and AR signaling pathways occurs through $\beta$-catenin, which can augment AR transcriptional activity [153-156]. Non-canonical Wnt signaling may also play a role in promoting prostate cancer cell survival [157]. A recent CTC transcriptome analysis has demonstrated that noncanonical Wnt signaling associates with enzalutamide 
drug resistance, and preclinical models suggest that WNT5A, a ligand of the non-canonical Wnt pathway, may abrogate the anti-tumor effects of AR inhibition.

Small molecule inhibitors of Wnt/ $\beta$-catenin have been developed and shown to inhibit proliferation in prostate cancer cells [158]. Clinical trials evaluating specific Wnt signaling inhibitors are currently underway (clinicaltrials.gov: NCT01608867), but have yet to be reported. In addition, there is evidence that the COX-2 inhibitor celecoxib is able to inhibit Wnt signaling, and a clinical trial testing celecoxib vs. placebo has been reported $[158,159]$. This trial was terminated early due to concerns over the cardiovascular morbidity associated with celecoxib. The celecoxib arm demonstrated only modest improvements in PSA dynamics and ultimately further development of COX-2 inhibitors as repurposed prostate cancer drugs seems unlikely.

\section{Conclusions}

Even in its late stages, AR signaling remains an important driver of prostate cancer progression, with most of the adaptive changes that occur within a prostate cancer cell stemming from a persistent addiction to the AR. As our understanding of the alterations that occur (e.g., $A R$ mutations, AR alternative splicing events, AR overexpression/copy number gains, AR substitutions, ligand persistence, and feedback pathways) in response to the evolutionary pressure exerted through chronic AR signaling inhibition, we will hopefully begin to see the emergence of therapeutic regimens that are able to impair key resistance mechanisms. Ideally, this will allow us to offer our patients a personalized regimen based on their cancer's molecular profile and the specific resistance mechanisms operative within them.

The incredible amount of molecular redundancy by which a malignant prostate cell is able to keep AR signaling engaged remains a critical barrier to the wide deployment of targeted, precision oncology. Clinical trials targeting these accessory pathways have, to date, been mostly unsuccessful. A key issue not addressed in past trials is the issue of cross talk between pathways other than the AR. It is likely that combination therapeutic trials are necessary if these other pathways are to be effectively targeted in the clinic.

Our understanding for how prostate cancers are able to progress in spite of drugs that should effectively prevent canonical AR signaling (i.e., abiraterone and enzalutamide) is growing exponentially. Armed with this improved understanding, the next challenge will be to take this knowledge and translate it into the next generation of targeted therapies-allowing us to extend the health and well-being of men suffering with the most advanced forms of CRPC.

\section{Competing interests}

The authors declare that they have no competing interests.

\section{Authors' contributions}

MTS and EYY contributed equally to the writing of the manuscript. Both authors read and approved the final manuscript.

Received: 24 September 2015 Accepted: 10 November 2015 Published online: 13 November 2015

\section{References}

1. Huggins C, Hodges CV. Studies on prostatic cancer. I. The effect of castration, of estrogen and of androgen injection on serum phosphatases in metastatic carcinoma of the prostate. 1941. J Urol. 2002;167(2 Pt 2):948-51. discussion 952.

2. Scher HI, Halabi S, Tannock I, Morris M, Sternberg CN, Carducci MA, et al. Design and end points of clinical trials for patients with progressive prostate cancer and castrate levels of testosterone: recommendations of the Prostate Cancer Clinical Trials Working Group. J Clin Oncol. 2008; 26(7):1148-59.

3. Scher HI, Morris MJ, Stadler WM, Higano CS, Halabi S, Smith MR, Basch EM, Fizazi K, Ryan CJ, Antonarakis ES, Corn PG, Liu G, De Bono JS, Schwartz LH, Beer TM, Kelly WK, Hussain M, Sartor AO, Kantoff PW, Armstrong AJ: The Prostate Cancer Working Group 3 (PCWG3) consensus for trials in castration-resistant prostate cancer (CRPC). In: American Society Of Clinical Oncology Annual Meeting: 2015; Chicago, IL

4. Scher HI, Sawyers CL. Biology of progressive, castration-resistant prostate cancer: directed therapies targeting the androgen-receptor signaling axis. J Clin Oncol. 2005;23(32):8253-61.

5. Beer TM, Armstrong AJ, Rathkopf DE, Loriot Y, Sternberg CN, Higano CS, et al. Enzalutamide in metastatic prostate cancer before chemotherapy. N Engl J Med. 2014;371:424-33.

6. de Bono JS, Logothetis CJ, Molina A, Fizazi K, North S, Chu L, et al. Abiraterone and increased survival in metastatic prostate cancer. N Engl J Med. 2011;364(21):1995-2005.

7. Ryan CJ, Smith MR, de Bono JS, Molina A, Logothetis CJ, de Souza P, et al. Abiraterone in metastatic prostate cancer without previous chemotherapy. N Engl J Med. 2013;368(2):138-48.

8. Scher HI, Fizazi K, Saad F, Taplin ME, Sternberg CN, Miller K, et al. Increased survival with enzalutamide in prostate cancer after chemotherapy. N Engl J Med. 2012;367(13):1187-97.

9. Antonarakis ES, Lu C, Wang H, Luber B, Nakazawa M, Roeser JC, et al. AR-V7 and resistance to enzalutamide and abiraterone in prostate cancer. $\mathrm{N}$ Engl J Med. 2014;371(11):1028-38.

10. Asangani IA, Dommeti VL, Wang X, Malik R, Cieslik M, Yang R, et al. Therapeutic targeting of BET bromodomain proteins in castration-resistant prostate cancer. Nature. 2014;510(7504):278-82.

11. Carreira S, Romanel A, Goodall J, Grist E, Ferraldeschi R, Miranda S, et al. Tumor clone dynamics in lethal prostate cancer. Sci Transl Med. 2014;6(254): $254 \mathrm{ra} 125$.

12. Chang KH, Li R, Kuri B, Lotan Y, Roehrborn CG, Liu J, et al. A gain-of-function mutation in DHT synthesis in castration-resistant prostate cancer. Cell. 2013; 154(5):1074-84.

13. Chen CD, Welsbie DS, Tran C, Baek SH, Chen R, Vessella R, et al. Molecular determinants of resistance to antiandrogen therapy. Nat Med. 2004;10(1):33-9.

14. Cho E, Montgomery RB, Mostaghel EA. Minireview: SLCO and ABC transporters: a role for steroid transport in prostate cancer progression. Endocrinology. 2014;155(11):4124-32.

15. Drake JM, Graham NA, Lee JK, Stoyanova T, Faltermeier CM, Sud S, et al. Metastatic castration-resistant prostate cancer reveals intrapatient similarity and interpatient heterogeneity of therapeutic kinase targets. Proc Natl Acad Sci U S A. 2013;110(49):E4762-4769.

16. Evaul K, Li R, Papari-Zareei M, Auchus RJ, Sharifi N. 3beta-hydroxysteroid dehydrogenase is a possible pharmacological target in the treatment of castration-resistant prostate cancer. Endocrinology. 2010;151(8):3514-20.

17. Li Z, Bishop AC, Alyamani M, Garcia JA, Dreicer R, Bunch D, et al. Conversion of abiraterone to D4A drives anti-tumour activity in prostate cancer. Nature. 2015;523(7560):347-51. 
18. Malik R, Khan AP, Asangani IA, Cieslik M, Prensner JR, Wang X, et al. Targeting the MLL complex in castration-resistant prostate cancer. Nat Med. 2015;21(4):344-52.

19. Montgomery RB, Mostaghel EA, Vessella R, Hess DL, Kalhorn TF, Higano CS, et al. Maintenance of intratumoral androgens in metastatic prostate cancer: a mechanism for castration-resistant tumor growth. Cancer Res. 2008;68(11): 4447-54.

20. Mostaghel EA, Marck BT, Plymate SR, Vessella RL, Balk S, Matsumoto AM, et al. Resistance to CYP17A1 inhibition with abiraterone in castration-resistant prostate cancer: induction of steroidogenesis and androgen receptor splice variants. Clin Cancer Res. 2011;17(18):5913-25.

21. Mostaghel EA, Solomon KR, Pelton K, Freeman MR, Montgomery RB. Impact of circulating cholesterol levels on growth and intratumoral androgen concentration of prostate tumors. PLoS One. 2012;7(1):e30062.

22. Wright JL, Kwon EM, Ostrander EA, Montgomery RB, Lin DW, Vessella R, et al. Expression of SLCO transport genes in castration-resistant prostate cancer and impact of genetic variation in SLCO1B3 and SLCO2B1 on prostate cancer outcomes. Cancer Epidemiol Biomarkers Prev. 2011; 20(4):619-27.

23. Yang $M$, Xie W, Mostaghel E, Nakabayashi M, Werner L, Sun T, et al. SLCO2B1 and SLCO1B3 may determine time to progression for patients receiving androgen deprivation therapy for prostate cancer. J Clin Oncol. 2011;29(18):2565-73.

24. Yeh S, Lin HK, Kang HY, Thin TH, Lin MF, Chang C. From HER2/Neu signal cascade to androgen receptor and its coactivators: a novel pathway by induction of androgen target genes through MAP kinase in prostate cancer cells. Proc Natl Acad Sci U S A. 1999;96(10):5458-63.

25. Yu Z, Chen S, Sowalsky AG, Voznesensky OS, Mostaghel EA, Nelson PS, et al. Rapid induction of androgen receptor splice variants by androgen deprivation in prostate cancer. Clin Cancer Res. 2014;20(6):1590-600.

26. Tan MH, Li J, Xu HE, Melcher K, Yong EL. Androgen receptor: structure, role in prostate cancer and drug discovery. Acta Pharmacol Sin. 2015;36(1):3-23.

27. Lu C, Luo J. Decoding the androgen receptor splice variants. Transl Andrology Urol. 2013;2(3):178-86.

28. Koryakina $Y, T a H Q$, Gioeli D. Androgen receptor phosphorylation: biological context and functional consequences. Endocr Relat Cancer. 2014;21(4):T131-145.

29. Garraway LA, Sellers WR. Lineage dependency and lineage-survival oncogenes in human cancer. Nat Rev Cancer. 2006;6(8):593-602.

30. Nelson PS. Molecular states underlying androgen receptor activation: a framework for therapeutics targeting androgen signaling in prostate cancer. J Clin Oncol. 2012;30(6):644-6

31. Robinson D, Van Allen EM, Wu YM, Schultz N, Lonigro RJ, Mosquera JM, et al. Integrative clinical genomics of advanced prostate cancer. Cell. 2015; 161(5):1215-28.

32. Ryan CJ, Smith MR, Fizazi K, Saad F, Mulders PF, Sternberg CN, et al. Abiraterone acetate plus prednisone versus placebo plus prednisone in chemotherapy-naive men with metastatic castration-resistant prostate cancer (COU-AA-302): final overall survival analysis of a randomised, double-blind, placebo-controlled phase 3 study. Lancet Oncol. 2015; 16(2):152-60

33. Salvi S, Casadio V, Conteduca V, Burgio SL, Menna C, Bianchi E, et al Circulating cell-free AR and CYP17A1 copy number variations may associate with outcome of metastatic castration-resistant prostate cancer patients treated with abiraterone. Br J Cancer. 2015;112(10): 1717-24.

34. Azad AA, Volik SV, Wyatt AW, Haegert A, Le Bihan S, Bell RH, et al. Androgen receptor gene aberrations in circulating cell-free DNA: biomarkers of therapeutic resistance in castration-resistant prostate cancer. Clin Cancer Res. 2015:21(10):2315-24

35. Tamae D, Mostaghel E, Montgomery B, Nelson PS, Balk SP, Kantoff PW, et al. The DHEA-sulfate depot following P450c17 inhibition supports the case for AKR1C3 inhibition in high risk localized and advanced castration resistant prostate cancer. Chem Biol Interact. 2015;234:332-8.

36. Taplin ME, Montgomery B, Logothetis CJ, Bubley GJ, Richie JP, Dalkin $\mathrm{BL}$, et al. Intense androgen-deprivation therapy with abiraterone acetate plus leuprolide acetate in patients with localized high-risk prostate cancer: results of a randomized phase II neoadjuvant study. J Clin Oncol. 2014;32(33):3705-15.

37. Shah RB, Mehra R, Chinnaiyan AM, Shen R, Ghosh D, Zhou M, et al. Androgen-independent prostate cancer is a heterogeneous group of diseases: lessons from a rapid autopsy program. Cancer Res. 2004; 64(24):9209-16.

38. Mostaghel EA, Morgan A, Zhang X, Marck BT, Xia J, Hunter-Merrill R, et al. Prostate cancer characteristics associated with response to pre-receptor targeting of the androgen axis. PLoS One. 2014;9(10):e111545.

39. Mostaghel EA, Page ST, Lin DW, Fazli L, Coleman IM, True LD, et al. Intraprostatic androgens and androgen-regulated gene expression persist after testosterone suppression: therapeutic implications for castration-resistant prostate cancer. Cancer Res. 2007;67(10):5033-41.

40. Titus MA, Schell MJ, Lih FB, Tomer KB, Mohler JL. Testosterone and dihydrotestosterone tissue levels in recurrent prostate cancer. Clin Cancer Res. 2005;11(13):4653-7.

41. Liu C, Lou W, Zhu Y, Yang JC, Natiminty N, Gaikwad N, et al. Intracrine androgens and AKR1C3 activation confer resistance to enzalutamide in prostate cancer. Cancer Res. 2015;75(7):1413-22.

42. Cai C, Chen S, Ng P, Bubley GJ, Nelson PS, Mostaghel EA, et al. Intratumoral de novo steroid synthesis activates androgen receptor in castration-resistant prostate cancer and is upregulated by treatment with CYP17A1 inhibitors. Cancer Res. 2011;71(20):6503-13.

43. Desmond JC, Mountford JC, Drayson MT, Walker EA, Hewison M, Ride JP, et al. The aldo-keto reductase AKR1C3 is a novel suppressor of cell differentiation that provides a plausible target for the non-cyclooxygenasedependent antineoplastic actions of nonsteroidal anti-inflammatory drugs. Cancer Res. 2003;63(2):505-12.

44. Liedtke AJ, Adeniji AO, Chen M, Byrns MC, Jin Y, Christianson DW, et al. Development of potent and selective indomethacin analogues for the inhibition of AKR1C3 (Type 5 17beta-hydroxysteroid dehydrogenase/ prostaglandin $\mathrm{F}$ synthase) in castrate-resistant prostate cancer. J Med Chem. 2013:56(6):2429-46.

45. Sharifi N. Mechanisms of androgen receptor activation in castration-resistant prostate cancer. Endocrinology. 2013;154(11):4010-7.

46. Hamada A, Sissung T, Price DK, Danesi R, Chau CH, Sharifi N, et al. Effect of SLCO1B3 haplotype on testosterone transport and clinical outcome in caucasian patients with androgen-independent prostatic cancer. Clin Cancer Res. 2008;14(11):3312-8.

47. Sharifi N, Hamada A, Sissung T, Danesi R, Venzon D, Baum C, et al. A polymorphism in a transporter of testosterone is a determinant of androgen independence in prostate cancer. BJU Int. 2008;102(5):617-21.

48. Kantoff PW, Wang X, Xie W, Nakabayashi M, Pomerantz M, Lee GM: Genetic variants of the organic anion transporter SLCO2B1 as pharmacogenomic determinants of response to androgen deprivation therapy (ADT) for prostate cancer. In: Genitourinary Cancers Symposium: 2015; Orlando, FL.

49. Mostaghel EA, Wright JL, Kwon EM, Montgomery RB, Ostrander EA, Vessella $R$, Nelson P, Stanford JL: Genetic variation in SLCO2B1, SLCO1B3, and prostate cancer risk and mortality. In: Genitourinary Cancers Symposium: 2010; San Francisco, CA.

50. Harshman LC, Wang X, Nakabayashi M, Xie W, Valenca L, Werner L, et al. Statin use at the time of initiation of androgen deprivation therapy and time to progression in patients with hormone-sensitive prostate cancer. JAMA Oncol. 2015;1(4):495-504

51. Ramos JD, Yu EY. Progress in understanding what is being statin(ed) in prostate cancer. JAMA Oncol. 2015;1(4):428-30.

52. Hu R, Denmeade SR, Luo J. Molecular processes leading to aberrant androgen receptor signaling and castration resistance in prostate cancer. Expert Rev Endocrinol Metab. 2010;5(5):753-64.

53. Dehm SM, Schmidt LJ, Heemers HV, Vessella RL, Tindall DJ. Splicing of a novel androgen receptor exon generates a constitutively active androgen receptor that mediates prostate cancer therapy resistance. Cancer Res. 2008;68(13):5469-77.

54. Hu R, Dunn TA, Wei S, Isharwal S, Veltri RW, Humphreys E, et al. Ligand-independent androgen receptor variants derived from splicing of cryptic exons signify hormone-refractory prostate cancer. Cancer Res. 2009;69(1):16-22.

55. Sun S, Sprenger CC, Vessella RL, Haugk K, Soriano K, Mostaghel EA et al. Castration resistance in human prostate cancer is conferred by a frequently occurring androgen receptor splice variant. J Clin Invest. 2010;120(8):2715-30.

56. Nadiminty N, Tummala R, Liu C, Yang J, Lou W, Evans CP, et al. NF-kappaB2/ p52 induces resistance to enzalutamide in prostate cancer: role of androgen receptor and its variants. Mol Cancer Ther. 2013;12(8):1629-37. 
57. Sharifi N. Steroid receptors aplenty in prostate cancer. N Engl J Med. 2014; 370(10):970-1.

58. Arora VK, Schenkein E, Murali R, Subudhi SK, Wongvipat J, Balbas MD, et al. Glucocorticoid receptor confers resistance to antiandrogens by bypassing androgen receptor blockade. Cell. 2013;155(6):1309-22.

59. Isikbay M, Otto K, Kregel S, Kach J, Cai Y, Vander Griend DJ, et al. Glucocorticoid receptor activity contributes to resistance to androgentargeted therapy in prostate cancer. Horm Cancer. 2014;5(2):72-89.

60. Efstathiou E, Troncoso P, Tapia EM, Davis JW, Titus MA, Hoang A, Prokhorova IN, Wen S, Logothetis CJ: Effects of preoperative abiraterone acetate (AA) plus enzalutamide (E) and leuprolide acetate (LHRHa) versus AA and LHRHa in localized high-risk prostate cancer (LHRPC). In: American Society of Clinical Oncology Annual Meeting: 2015; Chicago, IL.

61. Fenton MA, Shuster TD, Fertig AM, Taplin ME, Kolvenbag G, Bubley GJ, et al. Functional characterization of mutant androgen receptors from androgenindependent prostate cancer. Clin Cancer Res. 1997;3(8):1383-8.

62. Taplin ME, Bubley GJ, Ko YJ, Small EJ, Upton M, Rajeshkumar B, et al. Selection for androgen receptor mutations in prostate cancers treated with androgen antagonist. Cancer Res. 1999;59(11):2511-5.

63. Hara T, Miyazaki J, Araki H, Yamaoka M, Kanzaki N, Kusaka M, et al. Novel mutations of androgen receptor: a possible mechanism of bicalutamide withdrawal syndrome. Cancer Res. 2003;63(1):149-53.

64. Joseph JD, Lu N, Qian J, Sensintaffar J, Shao G, Brigham D, et al. A clinically relevant androgen receptor mutation confers resistance to second-generation antiandrogens enzalutamide and ARN-509. Cancer Discov. 2013:3(9):1020-9.

65. Korpal M, Korn JM, Gao X, Rakiec DP, Ruddy DA, Doshi S, et al. An F876L mutation in androgen receptor confers genetic and phenotypic resistance to MDV3100 (enzalutamide). Cancer Discov. 2013;3(9):1030-43.

66. Balbas MD, Evans MJ, Hosfield DJ, Wongvipat J, Arora VK, Watson PA, et al. Overcoming mutation-based resistance to antiandrogens with rational drug design. eLife. 2013;2:e00499.

67. Moilanen AM, Riikonen R, Oksala R, Ravanti L, Aho E, Wohlfahrt G, et al. Discovery of ODM-201, a new-generation androgen receptor inhibitor targeting resistance mechanisms to androgen signaling-directed prostate cancer therapies. Sci Rep. 2015;5:12007.

68. Fizazi K, Massard C, Bono P, Jones R, Kataja V, James N, et al. Activity and safety of ODM-201 in patients with progressive metastatic castration-resistant prostate cancer (ARADES): an open-label phase 1 dose-escalation and randomised phase 2 dose expansion trial. Lancet Oncol. 2014;15(9):975-85.

69. Guo Z, Yang $X$, Sun $F$, Jiang $R$, Linn DE, Chen $H$, et al. A novel androgen receptor splice variant is up-regulated during prostate cancer progression and promotes androgen depletion-resistant growth. Cancer Res. 2009;69(6):2305-13.

70. Hu R, Lu C, Mostaghel EA, Yegnasubramanian S, Gurel M, Tannahill C, et al. Distinct transcriptional programs mediated by the ligand-dependent fulllength androgen receptor and its splice variants in castration-resistant prostate cancer. Cancer Res. 2012;72(14):3457-62.

71. Antonarakis ES, Lu C, Luber B, Wang H, Chen Y, Nakazawa M, et al. Androgen receptor splice variant 7 and efficacy of taxane chemotherapy in patients with metastatic castration-resistant prostate cancer. JAMA Oncol. 2015;1(5):582-91.

72. Steinestel J, Luedeke M, Arndt A, Schnoeller TJ, Lennerz JK, Wurm C, Maier C, Cronauer MV, Steinestel K, Schrader AJ: Detecting predictive androgen receptor modifications in circulating prostate cancer cells. Oncotarget 2015, [Epub ahead of print]

73. Gelmann EP. Molecular biology of the androgen receptor. J Clin Oncol. 2002:20(13):3001-15.

74. Montgomery RB, Antonarakis ES, Hussain M, Fizazi K, Joshua AM, Attard G, Sadar M, Perabo F, Chi KN: A phase 1/2 open-label study of safety and antitumor activity of EPI-506, a novel AR N-terminal domain inhibitor, in men with metastatic castration-resistant prostate cancer (mCRPC) with progression after enzalutamide or abiraterone. In: American Society of Clinical Oncology Annual Meeting: 2015; Chicago, IL.

75. Yu Z, Cai C, Gao S, Simon NI, Shen HC, Balk SP. Galeterone prevents androgen receptor binding to chromatin and enhances degradation of mutant androgen receptor. Clin Cancer Res. 2014;20(15):4075-85.

76. Njar VC, Brodie AM. Discovery and development of Galeterone (TOK-001 or VN/124-1) for the treatment of all stages of prostate cancer. J Med Chem. 2015;58(5):2077-87.

77. Liu C, Lou W, Zhu Y, Nadiminty N, Schwartz CT, Evans CP, et al. Niclosamide inhibits androgen receptor variants expression and overcomes enzalutamide resistance in castration-resistant prostate cancer. Clin Cancer Res. 2014;20(12):3198-210.
78. Schweizer MT, Antonarakis ES, Wang H, Ajiboye AS, Spitz A, Cao H, et al. Effect of bipolar androgen therapy for asymptomatic men with castration-resistant prostate cancer: results from a pilot clinical study. Sci Transl Med. 2015;7(269):269ra262.

79. Dehm SM, Tindall DJ. Androgen receptor structural and functional elements: role and regulation in prostate cancer. Mol Endocrinol. 2007;21(12):2855-63.

80. Myung JK, Banuelos CA, Fernandez JG, Mawji NR, Wang J, Tien AH, et al. An androgen receptor $\mathrm{N}$-terminal domain antagonist for treating prostate cancer. J Clin Invest. 2013;123(7):2948-60.

81. Brand LJ, Olson ME, Ravindranathan P, Guo H, Kempema AM, Andrews TE, et al. EPI-001 is a selective peroxisome proliferator-activated receptor-gamma modulator with inhibitory effects on androgen receptor expression and activity in prostate cancer. Oncotarget. 2015; 6(6):3811-24.

82. Shang $\mathrm{Y}$, Myers $\mathrm{M}$, Brown $\mathrm{M}$. Formation of the androgen receptor transcription complex. Mol Cell. 2002;9(3):601-10.

83. Grasso CS, Wu YM, Robinson DR, Cao X, Dhanasekaran SM, Khan AP, et al. The mutational landscape of lethal castration-resistant prostate cancer. Nature. 2012;487(7406):239-43.

84. Welsbie DS, Xu J, Chen Y, Borsu L, Scher HI, Rosen N, et al. Histone deacetylases are required for androgen receptor function in hormone-sensitive and castrate-resistant prostate cancer. Cancer Res. 2009;69(3):958-66.

85. Molife LR, Attard G, Fong PC, Karavasilis V, Reid AH, Patterson S, et al. Phase II, two-stage, single-arm trial of the histone deacetylase inhibitor (HDACi) romidepsin in metastatic castration-resistant prostate cancer (CRPC). Ann Oncol. 2010;21(1):109-13.

86. Montgomery RB, Eisenberger MA, Heath El, Sartor AO, Chu F, Shore ND, Edenfield WJ, Koletsky AJ, Lipsitz DU, Cochran JS, Nordquist LT, Roberts J, Taplin ME: Galeterone in men with CRPC: Results in four distinct patient populations from the ARMOR2 study. In: American Society of Clinical Oncology Annual Meeting: 2014; Chicago, IL.

87. Roberts J, Dhillon R, Dransfield DT, Mamlouk KK, Ferrante KJ: Androgen Receptor Modulation Optimized for Response in Splice Variant (ARMOR3-SV): Randomized, open-label, multicenter, controlled study of galeterone versus enzalutamide (enz) in men expressing AR-V7 splice variant (SV), metastatic castrate resistant prostate cancer (mCRPC). In: Genitourinary Cancers Symposium: 2015; Orlando, FL.

88. Andrews P, Thyssen J, Lorke D. The biology and toxicology of molluscicides, Bayluscide. Pharmacol Ther. 1982;19(2):245-95.

89. Loriot $Y$, Bianchini D, lleana E, Sandhu S, Patrikidou A, Pezaro C, et al. Antitumour activity of abiraterone acetate against metastatic castrationresistant prostate cancer progressing after docetaxel and enzalutamide (MDV3100). Ann Oncol. 2013;24(7):1807-12.

90. Noonan KL, North S, Bitting RL, Armstrong AJ, Ellard SL, Chi KN. Clinical activity of abiraterone acetate in patients with metastatic castration-resistant prostate cancer progressing after enzalutamide. Ann Oncol. 2013;24(7):1802-7.

91. Schrader AJ, Boegemann M, OhImann CH, Schnoeller TJ, Krabbe LM, Hajili T, et al. Enzalutamide in castration-resistant prostate cancer patients progressing after docetaxel and abiraterone. Eur Urol. 2014;65(1):30-6.

92. Bianchini D, Lorente D, Rodriguez-Vida A, Omlin A, Pezaro C, Ferraldeschi R, et al. Antitumour activity of enzalutamide (MDV3100) in patients with metastatic castration-resistant prostate cancer (CRPC) pre-treated with docetaxel and abiraterone. Eur J Cancer. 2014;50(1):78-84.

93. Suzman DL, Luber B, Schweizer MT, Nadal R, Antonarakis ES. Clinical activity of enzalutamide versus docetaxel in men with castration-resistant prostate cancer progressing after abiraterone. Prostate. 2014;74(13):1278-85.

94. Badrising S, van der Noort V, van Oort IM, van den Berg HP, Los M, Hamberg P, et al. Clinical activity and tolerability of enzalutamide (MDV3100) in patients with metastatic, castration-resistant prostate cancer who progress after docetaxel and abiraterone treatment. Cancer. 2014;120(7):968-75.

95. Cheng HH, Gulati R, Azad A, Nadal R, Twardowski P, Vaishampayan UN, et al. Activity of enzalutamide in men with metastatic castration-resistant prostate cancer is affected by prior treatment with abiraterone and/or docetaxel. Prostate Cancer Prostatic Dis. 2015;18(2):122-7.

96. Azad AA, Eigl BJ, Murray RN, Kollmannsberger C, Chi KN. Efficacy of enzalutamide following abiraterone acetate in chemotherapy-naive metastatic castration-resistant prostate cancer patients. Eur Urol. 2015;67(1):23-9.

97. Taplin ME, Manola J, Oh WK, Kantoff PW, Bubley GJ, Smith M, et al. A phase II study of mifepristone (RU-486) in castration-resistant prostate cancer, with a correlative assessment of androgen-related hormones. BJU Int. 2008; 101(9):1084-9. 
98. Lonergan PE, Tindall DJ. Androgen receptor signaling in prostate cancer development and progression. J Carcinogenesis. 2011;10:20.

99. Wang Y, Mikhailova M, Bose S, Pan CX, deVere White RW, Ghosh PM. Regulation of androgen receptor transcriptional activity by rapamycin in prostate cancer cell proliferation and survival. Oncogene. 2008;27(56): 7106-17.

100. Li Y, Wang Z, Kong D, Li R, Sarkar SH, Sarkar FH. Regulation of Akt/FOXO3a/ GSK-3beta/AR signaling network by isoflavone in prostate cancer cells. J Biol Chem. 2008;283(41):27707-16

101. Bitting RL, Armstrong AJ. Targeting the PI3K/Akt/mTOR pathway in castration-resistant prostate cancer. Endocr Relat Cancer. 2013;20(3):R83-99.

102. Carver BS, Chapinski C, Wongvipat J, Hieronymus H, Chen Y, Chandarlapaty $\mathrm{S}$, et al. Reciprocal feedback regulation of PI3K and androgen receptor signaling in PTEN-deficient prostate cancer. Cancer Cell. 2011;19(5):575-86.

103. Gao J, Aksoy BA, Dogrusoz U, Dresdner G, Gross B, Sumer SO, et al. Integrative analysis of complex cancer genomics and clinical profiles using the cBioPortal. Sci Signal. 2013;6(269):11

104. Cerami E, Gao J, Dogrusoz U, Gross BE, Sumer SO, Aksoy BA, et al. The cBio cancer genomics portal: an open platform for exploring multidimensional cancer genomics data. Cancer Discov. 2012;2(5):401-4.

105. Chang L, Graham PH, Ni J, Hao J, Bucci J, Cozzi PJ, Li Y: Targeting PI3K/Akt/ mTOR signaling pathway in the treatment of prostate cancer radioresistance. Critical reviews in oncology/hematology 2015, doi: 10.1016/ j.critrevonc.2015.07.005.

106. Hsieh AC, Liu Y, Edlind MP, Ingolia NT, Janes MR, Sher A, et al. The translational landscape of mTOR signalling steers cancer initiation and metastasis. Nature. 2012;485(7396):55-61.

107. Dubrovska A, Kim S, Salamone RJ, Walker JR, Maira SM, Garcia-Echeverria C, et al. The role of PTEN/Akt/PI3K signaling in the maintenance and viability of prostate cancer stem-like cell populations. Proc Natl Acad Sci U S A. 2009;106(1):268-73.

108. Guba M, von Breitenbuch P, Steinbauer M, Koehl G, Flegel S, Hornung M, et al. Rapamycin inhibits primary and metastatic tumor growth by antiangiogenesis: involvement of vascular endothelial growth factor. Nat Med. 2002;8(2):128-35.

109. McMenamin ME, Soung P, Perera S, Kaplan I, Loda M, Sellers WR. Loss of PTEN expression in paraffin-embedded primary prostate cancer correlates with high Gleason score and advanced stage. Cancer Res. 1999; 59(17):4291-6.

110. Troyer DA, Jamaspishvili T, Wei W, Feng Z, Good J, Hawley S, et al. A multicenter study shows PTEN deletion is strongly associated with seminal vesicle involvement and extracapsular extension in localized prostate cancer. Prostate. 2015;75(11):1206-15.

111. Meulenbeld HJ, de Bono JS, Tagawa ST, Whang YE, Li X, Heath KH, et al. Tolerability, safety and pharmacokinetics of ridaforolimus in combination with bicalutamide in patients with asymptomatic, metastatic castrationresistant prostate cancer (CRPC). Cancer Chemother Pharmacol. 2013; 72(4):909-16.

112. Markman B, Tabernero J, Krop I, Shapiro Gl, Siu L, Chen LC, et al. Phase I safety, pharmacokinetic, and pharmacodynamic study of the oral phosphatidylinositol-3-kinase and mTOR inhibitor BGT226 in patients with advanced solid tumors. Ann Oncol. 2012;23(9):2399-408.

113. Nakabayashi M, Werner L, Courtney KD, Buckle G, Oh WK, Bubley GJ, et al. Phase II trial of RAD001 and bicalutamide for castration-resistant prostate cancer. BJU Int. 2012;110(11):1729-35.

114. Templeton AJ, Dutoit V, Cathomas R, Rothermundt C, Bartschi D, Droge C, et al. Phase 2 trial of single-agent everolimus in chemotherapy-naive patients with castration-resistant prostate cancer (SAKK 08/08). Eur Urol. 2013;64(1):150-8

115. Armstrong AJ, Shen T, Halabi S, Kemeny G, Bitting RL, Kartcheske P, et al. A phase II trial of temsirolimus in men with castration-resistant metastatic prostate cancer. Clin Genitourin Cancer. 2013;11(4):397-406.

116. Bendell JC, Rodon J, Burris HA, de Jonge $M$, Verweij J, Birle D, et al. Phase I, dose-escalation study of BKM120, an oral pan-Class I PI3K inhibitor, in patients with advanced solid tumors. J Clin Oncol. 2012; 30(3):282-90

117. Akinleye A, Avvaru P, Furqan M, Song Y, Liu D. Phosphatidylinositol 3-kinase (PI3K) inhibitors as cancer therapeutics. J Hematol Oncol. 2013;6(1):88.

118. Sarbassov DD, Ali SM, Sengupta S, Sheen JH, Hsu PP, Bagley AF, et al. Prolonged rapamycin treatment inhibits mTORC2 assembly and Akt/PKB Mol Cell. 2006;22(2):159-68.
119. Edlind MP, Hsieh AC. PI3K-AKT-mTOR signaling in prostate cancer progression and androgen deprivation therapy resistance. Asian J Androl. 2014;16(3):378-86

120. Traish AM, Morgentaler A. Epidermal growth factor receptor expression escapes androgen regulation in prostate cancer: a potential molecular switch for tumour growth. Br J Cancer. 2009;101(12):1949-56.

121. Berger R, Lin DI, Nieto M, Sicinska E, Garraway LA, Adams H, et al. Androgen-dependent regulation of Her-2/neu in prostate cancer cells. Cancer Res. 2006;66(11):5723-8

122. Lee MS, Igawa T, Yuan TC, Zhang XQ, Lin FF, Lin MF. ErbB-2 signaling is involved in regulating PSA secretion in androgen-independent human prostate cancer LNCaP C-81 cells. Oncogene. 2003;22(5):781-96.

123. Neto AS, Tobias-Machado M, Wroclawski ML, Fonseca FL, Teixeira GK, Amarante RD, et al. Her-2/neu expression in prostate adenocarcinoma: a systematic review and meta-analysis. J Urol. 2010;184(3):842-50.

124. Solit DB, Rosen N. Targeting HER2 in prostate cancer: where to next? J Clin Oncol. 2007:25(3):241-3.

125. Molife LR, Omlin A, Jones RJ, Karavasilis V, Bloomfield D, Lumsden G, et al. Randomized phase II trial of nintedanib, afatinib and sequential combination in castration-resistant prostate cancer. Future Oncol. 2014;10(2):219-31.

126. Liu G, Chen YH, Kolesar J, Huang W, Dipaola R, Pins M, et al. Eastern Cooperative Oncology Group Phase II Trial of lapatinib in men with biochemically relapsed, androgen dependent prostate cancer. Urol Oncol. 2013;31(2):211-8.

127. Whang YE, Armstrong AJ, Rathmell WK, Godley PA, Kim WY, Pruthi RS, et al. A phase II study of lapatinib, a dual EGFR and HER-2 tyrosine kinase inhibitor, in patients with castration-resistant prostate cancer. Urol Oncol. 2013;31(1):82-6.

128. Sridhar SS, Hotte SJ, Chin JL, Hudes GR, Gregg R, Trachtenberg J, et al. A multicenter phase II clinical trial of lapatinib (GW572016) in hormonally untreated advanced prostate cancer. Am J Clin Oncol. 2010;33(6):609-13.

129. Ziada A, Barqawi A, Glode LM, Varella-Garcia M, Crighton F, Majeski S, et al. The use of trastuzumab in the treatment of hormone refractory prostate cancer; phase II trial. Prostate. 2004;60(4):332-7.

130. de Bono JS, Bellmunt J, Attard G, Droz JP, Miller K, Flechon A, et al. Open-label phase II study evaluating the efficacy and safety of two doses of pertuzumab in castrate chemotherapy-naive patients with hormone-refractory prostate cancer. J Clin Oncol. 2007;25(3):257-62.

131. Joshi G, Singh PK, Negi A, Rana A, Singh S, Kumar R. Growth factors mediated cell signalling in prostate cancer progression: implications in discovery of antiprostate cancer agents. Chem Biol Interact. 2015;240:120-33.

132. Wu JD, Haugk K, Woodke L, Nelson P, Coleman I, Plymate SR. Interaction of IGF signaling and the androgen receptor in prostate cancer progression. J Cell Biochem. 2006:99(2):392-401.

133. Plymate SR, Tennant MK, Culp SH, Woodke L, Marcelli M, Colman I, et al. Androgen receptor (AR) expression in AR-negative prostate cancer cells results in differential effects of DHT and IGF-I on proliferation and AR activity between localized and metastatic tumors. Prostate. 2004;61(3):276-90.

134. Lin HK, Yeh S, Kang HY, Chang C. Akt suppresses androgen-induced apoptosis by phosphorylating and inhibiting androgen receptor. Proc Natl Acad Sci U S A. 2001;98(13):7200-5.

135. Cao Y, Nimptsch K, Shui IM, Platz EA, Wu K, Pollak MN, et al. Prediagnostic plasma IGFBP-1, IGF-1 and risk of prostate cancer. Int J Cancer. 2015;136(10): 2418-26.

136. Stattin P, Rinaldi S, Biessy C, Stenman UH, Hallmans G, Kaaks R. High levels of circulating insulin-like growth factor-l increase prostate cancer risk: a prospective study in a population-based nonscreened cohort. J Clin Oncol. 2004:22(15):3104-12

137. Chan JM, Stampfer MJ, Giovannucci E, Gann PH, Ma J, Wilkinson P, et al. Plasma insulin-like growth factor-I and prostate cancer risk: a prospective study. Science. 1998;279(5350):563-6.

138. Pollak M. Insulin-like growth factor physiology and cancer risk. Eur J Cancer. 2000;36(10):1224-8.

139. Yu EY, Li H, Higano CS, Agarwal N, Pal SK, Alva A, et al. SWOG S0925: a randomized phase II study of androgen deprivation combined with cixutumumab versus androgen deprivation alone in patients with new metastatic hormone-sensitive prostate cancer. J Clin Oncol. 2015;33(14):1601-8.

140. Hussain M, Rathkopf D, Liu G, Armstrong A, Kelly WK, Ferrari A, et al. A randomised non-comparative phase II trial of cixutumumab (IMC-A12) or ramucirumab (IMC-1121B) plus mitoxantrone and prednisone in men with metastatic docetaxel-pretreated castration-resistant prostate cancer. Eur J Cancer. 2015:51(13):1714-24. 
141. Adler HL, McCurdy MA, Kattan MW, Timme TL, Scardino PT, Thompson TC. Elevated levels of circulating interleukin- 6 and transforming growth factor-beta1 in patients with metastatic prostatic carcinoma. J Urol. 1999;161(1):182-7.

142. Shariat SF, Andrews B, Kattan MW, Kim J, Wheeler TM, Slawin KM. Plasma levels of interleukin- 6 and its soluble receptor are associated with prostate cancer progression and metastasis. Urology. 2001;58(6):1008-15.

143. Nakashima J, Tachibana M, Horiguchi Y, Oya M, Ohigashi T, Asakura H, et al. Serum interleukin 6 as a prognostic factor in patients with prostate cancer. Clin Cancer Res. 2000;6(7):2702-6.

144. George DJ, Halabi S, Shepard TF, Sanford B, Vogelzang NJ, Small EJ, et al. The prognostic significance of plasma interleukin-6 levels in patients with metastatic hormone-refractory prostate cancer: results from cancer and leukemia group B 9480. Clin Cancer Res. 2005;11(5):1815-20

145. Zhu ML, Kyprianou N. Androgen receptor and growth factor signaling cross-talk in prostate cancer cells. Endocr Relat Cancer. 2008;15(4):841-9.

146. Aaronson DS, Muller M, Neves SR, Chung WC, Jayaram G, lyengar R, et al. An androgen-IL-6-Stat3 autocrine loop re-routes EGF signal in prostate cancer cells. Mol Cell Endocrinol. 2007;270(1-2):50-6.

147. Karkera J, Steiner H, Li W, Skradski V, Moser PL, Riethdorf S, et al. The anti-interleukin-6 antibody siltuximab down-regulates genes implicated in tumorigenesis in prostate cancer patients from a phase I study. Prostate. 2011;71(13):1455-65.

148. Hudes G, Tagawa ST, Whang YE, Qi M, Qin X, Puchalski TA, et al. A phase 1 study of a chimeric monoclonal antibody against interleukin-6, siltuximab, combined with docetaxel in patients with metastatic castration-resistant prostate cancer. Investig New Drugs. 2013;31(3):669-76.

149. Tannock IF, de Wit R, Berry WR, Horti J, Pluzanska A, Chi KN, et al. Docetaxel plus prednisone or mitoxantrone plus prednisone for advanced prostate cancer. N Engl J Med. 2004;351(15):1502-12.

150. Petrylak DP, Tangen CM, Hussain MH, Lara Jr PN, Jones JA, Taplin ME, et al. Docetaxel and estramustine compared with mitoxantrone and prednisone for advanced refractory prostate cancer. N Engl J Med. 2004;351(15):1513-20.

151. Fizazi K, De Bono JS, Flechon A, Heidenreich A, Voog E, Davis NB, et al. Randomised phase II study of siltuximab (CNTO 328), an anti-IL-6 monoclonal antibody, in combination with mitoxantrone/prednisone versus mitoxantrone/prednisone alone in metastatic castration-resistant prostate cancer. Eur J Cancer. 2012:48(1):85-93.

152. Verras M, Sun Z. Roles and regulation of Wnt signaling and beta-catenin in prostate cancer. Cancer Lett. 2006;237(1):22-32

153. Mulholland DJ, Cheng H, Reid K, Rennie PS, Nelson CC. The androgen receptor can promote beta-catenin nuclear translocation independently of adenomatous polyposis coli. J Biol Chem. 2002:277(20):17933-43.

154. Truica $\mathrm{Cl}$, Byers S, Gelmann EP. Beta-catenin affects androgen receptor transcriptional activity and ligand specificity. Cancer Res. 2000;60(17): 4709-13.

155. Chesire DR, Isaacs WB. Beta-catenin signaling in prostate cancer: an early perspective. Endocr Relat Cancer. 2003;10(4):537-60.

156. Yang F, Li X, Sharma M, Sasaki CY, Longo DL, Lim B, et al. Linking beta-catenin to androgen-signaling pathway. J Biol Chem. 2002;277(13): $11336-44$.

157. Miyamoto DT, Zheng $Y$, Wittner BS, Lee RJ, Zhu H, Broderick KT, et al. RNA-Seq of single prostate CTCs implicates noncanonical Wht signaling in antiandrogen resistance. Science. 2015;349(6254):1351-6.

158. Lu W, Tinsley HN, Keeton A, Qu Z, Piazza GA, Li Y. Suppression of Wnt/ beta-catenin signaling inhibits prostate cancer cell proliferation. Eur J Pharmacol. 2009;602(1):8-14.

159. Smith MR, Manola J, Kaufman DS, Oh WK, Bubley GJ, Kantoff PW. Celecoxib versus placebo for men with prostate cancer and a rising serum prostate-specific antigen after radical prostatectomy and/or radiation therapy. J Clin Oncol. 2006;24(18):2723-8.

\section{Submit your next manuscript to BioMed Central and take full advantage of:}

- Convenient online submission

- Thorough peer review

- No space constraints or color figure charges

- Immediate publication on acceptance

- Inclusion in PubMed, CAS, Scopus and Google Scholar

- Research which is freely available for redistribution

Submit your manuscript at www.biomedcentral.com/submit 